\title{
A ARTE E O MERCADO: UMA PROBLEMATIZAÇÃO TEÓRICO-LITERÁRIA EM ADORNO E MÁRIO DE SÁ-CARNEIRO
}

Marcelo Chiaretto Universidade Federal de Minas Gerais

"A arte é a promessa de felicidade que se quebra."

Adorno

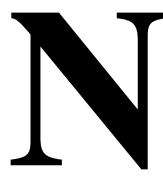

ão seria novidade afirmar-se que as obras literárias do escritor português Mário de Sá-Carneiro determinam para si mesmas a necessidade de um leitor inquieto, ágil, ativo - em suma, moderno - tendo em vista a fundamentalidade de sua participação, ou melhor, da sua produção no processo de criação literária. Com efeito, percebe-se uma explícita ênfase na competên-cia da recepção, o que, se por um lado, a valoriza, revela, por outro lado, um certo eruditismo. Diante disso, é necessário apontar que, como todo processo que versa sobre a exigência de uma maior criticidade do público, não há dúvidas sobre o fato de tal característica implicar em certas obras numa leitura elitizada, diferenciada e individual, que não é assegurada obviamente para todos os leitores.

\section{Uma romântica negatividade}

Adorno, um dos teóricos da Escola de Frankfurt, foi um dos grandes defensores de processos que pudessem valorizar a recepção das obras de arte. Para ele, "a ininteligibilidade que se censura nas obras de arte herméticas é o reconhecimento do caráter enigmático 
de toda a arte". ${ }^{1}$ Essa afirmação implica em redefinir o valor da negatividade expressional, um recurso que, segundo o filósofo, seria primordial para garantir o mistério e a ambigüidade, traços que, no seu ponto de vista, estariam aptos a consolidar a inesgotabilidade fundamental de toda arte.

É interessante relembrar que Hegel - outro teórico interessado, dentre outros aspectos, na conformação das recepções artísticas -, criticou o supracitado procedimento por "intentar a favor da morte e da dissolução do processo artístico", ao reduzir as obras a uma existência "vazia e caprichosa", cuja decifração dependia de um leitor capaz de mergulhar na "inexpugnável e total interioridade de um autor", retratado como "vaidoso e egocêntrico". ${ }^{2}$ Hegel reivindicava a legibilidade, a necessidade de uma recepção tranqüila, um conteúdo com "um caráter verdadeiro" e com "finalidades essenciais", capaz de proporcionar um "meio para fins morais". ${ }^{3}$ Enquanto "picardia contra o público", segundo ele, os recursos que colocavam como primordial a valorização do receptor manifestariam então uma teimosia pela originalidade e uma incompetência ao serem incapazes de expressar o "sentimento e o espírito da nação alemã e de seu tempo". ${ }^{4}$

Considerando-se que tais críticas foram realizadas por Hegel como uma forma de se contrapor à teoria romântica sobre a negatividade na arte - concepções formuladas pelos alemães F. Schlegel e Novalis -, Adorno estabelece assim, após um considerável espaço de tempo, uma espécie de resposta às críticas supramencionadas. Destaca-se que essa "resposta", por parte dos românticos, nunca aconteceu, uma vez que no momento das críticas hegelianas Schlegel, por exemplo, já não estava interessado em teorizar sobre a negatividade, e Novalis, por seu lado, já havia precocemente morrido. Interessado

\footnotetext{
${ }^{1}$ ADORNO, 1980, p.143.

${ }^{2}$ HEGEL apud FINLAY, 1988, p.14-15.

${ }^{3}$ Ibidem, p.14-15.

${ }^{4}$ Ibidem, p.15.
} 
na conexão materialista possível de ser depreendida da idéia de negatividade expressional - além da perspectiva dialética e política - Adorno dessa maneira buscou valorizá-la por seu próprio aparato erudito, elitista e original.

A recusa de sentido definitivo, a ênfase no material da arte e nas limitações desse material, - e aqui se inicia uma possível explicação da citada conexão materialista - somados ao descompro-misso com o Geist (o espírito da nação alemã, ponto de referência para a criação artística, segundo Hegel), observados então na teoria romântica relacionada ao valor da negatividade expresional na arte, seriam fundamentais, conforme Adorno, para que fossem logrados dois objetivos:

$1^{\text {o }}$ - ao enfatizar o seu material - entendendo-se como "material" as características ou procedimentos específicos de composição fundando-se mais apresentativa do que representativa, a obra de arte exigiria de seus receptores uma leitura crítica e reflexiva, tornando difícil a perspectiva do prazer, ou melhor, do entretenimento. É imperioso apontar que Adorno referia esse prazer como um reflexo da perversão burguesa:

Quem saboreia concretamente as obras de arte é um filisteu; expressões como 'delicioso para o ouvido' bastam para o convencer. [...] Na realidade, quanto mais se compreendem as obras de arte, tanto menos se saboreiam. É incontestável, como afirmam os burgueses, que ninguém se votaria à arte se dela nada retirasse. No entanto, semelhante estupidez erigiu-se em bom senso. O burguês deseja que a arte seja voluptuosa e a vida ascética; o contrário seria melhor. 5

Observa-se nas palavras de Adorno uma escala inversamente proporcional: quanto mais prazer, menos reflexão. Na perspectiva "burguesa" firmada na idéia da voluptuosidade na arte, as obras estavam próximas de se tornarem mercadorias, bens utilizáveis, tão distantes da realidade quanto alienadores. Segundo Adorno, quem desaparece

${ }^{5}$ ADORNO, 1980, p.24-25. 
na obra de arte é dispensado da miséria de uma vida, o que indicaria como melhor posicionamento para o receptor o distanciamento, através do qual alcançaria uma visão desmitificadora da arte e desveladora da realidade social, tendo em vista a ruptura da ilusão. Chega-se assim ao segundo objetivo:

$2^{\text {o }}$ - Conforme as concepções do filósofo alemão, a experiência estética é tão ou mais genuína na proporção em que cada vez mais se prive do entretenimento ou do prazer estético. ${ }^{6}$ Essa privação poderia afirmar uma nova postura diante da arte: em oposição à idéia de mergulhar na leitura aceitando o dito pelo dito, e, dessa forma, alienando-se dos supostos interesses camu-flados do poder, o receptor poderia se distanciar da narrativa ao descobrir o não-dito sobre o dito (ou o dito como implicação do não-dito), permitindo à arte a realização de sua única função possível dentro da sociedade burguesa, qual seja, a de educar.

Para Adorno, quanto mais a obra é autônoma - "não-coisificada ou entorpecida" ${ }^{7}$, sim, livre de obrigações referentes à legibilidade e ao prazer - mais aumenta o poder do sujeito da leitura. ${ }^{8}$ Reconhecendo-se o fracasso da cultura quando se observa sua inclusão dentro da indústria do consumo, a arte - auto-consciente, mergulhada na negatividade expressional - surgiria como único elemento capaz de combater o processo mercantil, pois estaria apta a expor ao público o seu eloqüente e enigmático mutismo, protestando a favor de uma decifração reflexiva, crítica, transformadora da realidade.

Em contato com essa arte, o público poderia ser capaz de conhecer a estrutura fundante das obras de arte e compreender a elaboração estética do autor; determinaria, ao mesmo tempo, a ação

${ }^{6}$ É importante acrescentar que o que Adorno chama de "prazer", Roland Barthes, por exemplo, chama de "deleite" (jouissance), isto é, o prazer estético negativo. Cf. JAUSS, 1979, p.73.

${ }^{7}$ ADORNO, 1980, p.33.

${ }^{8}$ Ibidem, p.26. 
do leitor não-ingênuo, aquele consciente de sua função no processo que possibilita a sobrevivência da arte numa sociedade que a despreza. Para Adorno, a única mimesis permitida à arte moderna é a mimesis do que está petrificado e alienado, ${ }^{9}$ ou seja, daquilo que perdeu sua identidade. Segundo ele: "menos do que imitar a natureza, as obras de arte traduzem a sua transposição em elementos da reali-dade. Em última análise, deveria derrubar-se a doutrina da imitação; num sentido sublimado, a realidade deve imitar as obras de arte". ${ }^{10}$

Por mais utópica que pareça, a proposta de Adorno revelaria um impulso em enfocar na arte o seu efeito desconstrucionista ao colocála como apta não apenas a expressar a sua materialidade, mas também de "traduzir a sua transposição em elementos da realidade". Pode-se pensar que, para Adorno, a "verdadeira" obra de arte é aquela capaz de ativar múltiplas reflexões sobre a forma com que se explica enquanto transposição de elementos da realidade ou enquanto produto de uma busca (incessante) pela referencialização. Com efeito, é essa transposição que funda a mimesis. A realidade, portanto, deveria tomar a arte como exemplo, já que se firma de forma estagnada e inconteste.

É interessante lembrar que Walter Benjamin também se preocupou em estudar o papel da negatividade no conceito de crítica de arte do romantismo alemão. Seu enfoque sociológico, contudo, não é similar ao de Adorno. O teor marxista fica bem destacado em ambos os casos, ao se considerar as constantes afirmações favoráveis à arte que procura educar o receptor ou, em outras palavras, que busca determinar-lhe uma postura radical e crítica, sem que seja gerado prazer ou identificação. Uma frase de Adorno, sobre isso, é extremamente significativa: "As obras de arte que se apresentam sem resíduo à reflexão e ao pensamento não são obras de arte". ${ }^{11}$

\footnotetext{
${ }^{9}$ Ibidem, p.33.

${ }^{10}$ Ibidem, p.153.

${ }^{11}$ Ibidem, p.142-143.
} 


\section{Um paradigma em Mário de Sá-Carneiro}

Em A confissão de Lúcio, ${ }^{12}$ obra do português Mário de SáCarneiro cuja complexidade de recepção é objeto de estudos reiterados, são identificáveis certos momentos em que se evidencia uma problematização do processo mercantil onde estão inseridas as obras de arte. Há, da mesma forma, uma manifesta preocupação com o público, ou seja, com a qualidade deste público. O escultor Gervásio Vila-Nova - uma das personagens que compõe a narrativa -, por exemplo, diz ter "muita pena de que não gostem das minhas obras", obras que, segundo o narrador Lúcio, eram: "esculturas sem pés nem cabeça, pois ele só esculpia torsos contorcidos, enclavinha-dos, monstruosos, onde, porém, de quando em quando, por alguns detalhes, se adivinhava um cinzel admirável”. E o escultor continua:

- Mas não pense que é por mim. Eu estou certo do que valem. É por eles, coitados, que não podem sentir a sua beleza. [...] Creia, meu querido amigo, você faz muito mal em colaborar nessas revistecas lá de baixo... em se apressar tanto a imprimir os seus volumes. O verdadeiro artista deve guardar quanto mais possível o seu inédito. Veja se eu já expus alguma vez... Só compreendo que se publique um livro numa tiragem reduzida; e a 100 francos o exemplar, como fez o .......] Ah! eu abomino a publicidade!...(p.77).

De acordo com a narração de Lúcio, Gervásio realiza uma clara reflexão sobre a ininteligibilidade de suas obras e das obras em geral. Para ele, aqueles que não gostam de suas obras - melhor dizendo, aqueles que não as entendem - são uns "coitados", são eles, em itálico no texto, um grupo causador de repulsa. Lúcio se mantém na sua ironia habitual quando o assunto são as obras que afirmam estar a arte na ausência de sentido, o que basta para a conclusão de que são "monstruosas e raramente admiráveis" as esculturas de Gervásio. Para

\footnotetext{
12 SÁ-CARNEIRO, s/d. As indicações de páginas entre parênteses se referem a essa edição.
} 
o escultor, é fundamental manter a dificuldade de acesso à arte, incluindo-se aí o acesso físico, seja "guardando quanto mais possível os inéditos", seja "publicando em tiragem reduzida", seja cobrando uma exorbitância pelos exemplares. Em suma, o verdadeiro artista deve abominar a publicidade.

E quanto ao narrador Lúcio, quais as suas concepções? Estas se delineiam em trechos curtos, mas significativos de sua narrativa. Ao contrário do que parece acontecer com as obras de Gervásio, a produção da personagem revela-se bem sucedida:

A minha vida desensombrara-se. Certas circunstâncias materiais muito enervantes tinham-se-me modificado lisonjeiramente. Ao meu último volume, recém-saído do prelo, estava-o acolhendo um magnífico sucesso. O próprio Sarzedas lhe dedicara um grande artigo elogioso e lúcido!... (p.94).

Nota-se uma certa apreensão pelo sucesso com o público e com a crítica: o primeiro proporcionaria a remediação para as "enervantes circunstâncias materiais", em outras palavras, dinheiro; a segunda (a crítica) representaria o reconhecimento no meio artístico. É uma possível interpretação para o "magnífico sucesso" ventilado por Lúcio.

Mais reveladores são os trechos referentes ao encontro do narrador com o "grande empresário Santa-Cruz de Vilalva" e sua conseqüências:

Fora-me muito desagradável o encontro que viera pôr termo ao meu isolamento de há seis meses. Porém, ao mesmo tempo, no fundo, a verdade é que eu não o lastimava. Sempre a literatura... Desde que chegara a Paris, não escrevera uma linha - nem sequer já me lembrava de que era um escritor... E agora, de súbito, vinham-me recordá-lo - evidenciando o apreço em que se tinha o meu nome; e precisamente alguém que eu sabia tão pouco lisonjeiro, tão brusco, tão homem de negócios... (p.128).

O empresário tem ótima impressão da peça de Lúcio - A chama -, reúne o elenco e inicia os ensaios. Acresce que Lúcio tem outra idéia para o último ato, leva as modificações para o empresário e este as rejeita, considerando-as um "disparate”. A reação de Lúcio é violenta e extremamente conclusiva: 
Uma raiva excessiva me afogueou perante a boçalidade do empresário, a sua pouca clarividência. Pois se algumas vezes eu adivinhara nas minhas obras lampejos de gênio, era nessas páginas. Mas tive a força de me conter. [...] Quebrei as relações com um e com outros, e exigi que me entregassem todas as cópias do manuscrito e os papéis. [...] Ao chegar a minha casa juntamente com o manuscrito original, lancei tudo ao fogo. Tal foi o destino da minha última obra. [...] O caso da Chama aborrecera-me deveras. Uma grande náusea me subira por tudo quanto tocava à arte no seu aspecto mercantil. Pois só o comércio condenara a versão nova da minha peça: com efeito, em vez de ser um acto mera-mente teatral, de acção intensa mas lisa, como o primitivo - o acto novo era profundo e inquietador; rasgava véus sobre o Além (p.129-130).

Caracteriza-se novamente o tom enfastiado com que o narrador trata a literatura. Seria interessante atentar melhor para essas referências: todas evidenciam a idéia de que a literatura para Lúcio denota um compromisso com o lado mundano e antipático da publicidade. É uma contradição com o trecho anterior em que ele exalta o seu sucesso - a não ser que para ele a única utilidade deste sucesso fosse o poder material proporcionado. A conclusão é realmente complicada. Nesses últimos exemplos, os negócios, "tão pouco lisonjeiros", "tão bruscos", caracterizam o lado "boçal e pouco clarividente" do empresário - diante da genialidade do artista. Percebe-se bem a opção pelo monologismo ao preferir destruir a obra a submetê-la aos caprichos do mercado. O "comércio" é destacado em itálico, numa referência semelhante ao anteriormente mencionado eles, evidenciando novamente a repulsa, a náusea que, neste caso, é claramente enunciada. Para o narrador, melhor que o ato primitivo, "meramente teatral", seria o ato novo, "profundo e inquietador", talvez mais complexo, mais artístico, mais descompro-missado com relação aos anseios do mundo do comércio.

Declara-se um desprezo pelo mercado e pela indústria de consumo, como também se afirma um impulso por um público oposto ao do lepidóptero burguês (termo cunhado por Mário de Sá-Carneiro e Fernando Pessoa indicando a classe abastada e inculta, aqueles que viam na arte apenas o que lhes conviesse): um público afinado, erudito e elitista, capaz de compreender e aplaudir a arte por eles instaurada. 
Todavia, se o enunciado pode expressar tais concepções, a enunciação - em procedimento comum na obra - a contradiz. A ânsia pelo entretenimento, observada na manipulação de elementos do mistério e da polêmica (analisados em seguida), manifesta um desejo do autor no sentido de tornar sua obra mais atraente ao público, o que determina uma espécie de consideração para com essa coletividade. A contradição é melhor retratada se se atenta para a manipulação de certos elementos no texto. Vilma Arêas, em suas "Anotações sobre o drama-em-texto de Sá-Carneiro", ${ }^{13}$ conclui da prosa sacarneiriana um "promíscuo convívio do Ideal com o reles, à mescla de uma literatura de corte aristocrático com formas comerciais de ficção". ${ }^{14}$ A autora permite deduzir pela existência, na literatura deste autor, de um impulso pendular, que ora tende para a arte como resistência, ora tende para o conformismo.

Enquanto resistência, referir-se-iam as formas de captar a realidade, buscando uma linguagem auto-referencial apta a traduzir idéias e valores, combinando o caótico mundo exterior com a subjetividade. A constatação da negatividade expressional é uma maneira condizente de firmar a obra de Sá-Carneiro, pelo menos no que tange à Confissão de Lúcio, como inserida na resistência, e é isso que a relaciona com as concepções anteriormente citadas de Adorno. Além de outros exemplos já salientados, deve-se lembrar que Lúcio, em respeito ao seu compromisso estético, chega mesmo a preferir queimar a sua obra a modelá-la segundo os desejos do empresário Vilalva.

Enquanto conformismo, avistar-se-ia uma ânsia que poderia variar entre a afirmação de um perfil popular historicamente consciente - incorporando o progresso e patenteando uma literatura comercial e a afirmação de uma literatura a-histórica, desprovida da noção de classe social e mesmo da consciência de "classe". Considerando-se o

\footnotetext{
${ }^{13}$ ARÊAS. In: Anais da Semana de Estudos Mário de Sá-Carneiro, 1994.

${ }^{14}$ Ibidem, p.59.
} 
fato de que, enquanto resistência, a obra em questão já está caracterizada, deve-se então partir para a análise do caráter de acomodação.

É interessante apontar, primordialmente, o aspecto folhetinesco da obra: há o melodramático e tradicional triângulo amoroso marido-esposa-amante, representados por Ricardo, Marta e Lúcio. Para supostamente permitir, da mesma forma, uma melhor publicidade da obra com vistas a atrair consumidores, há o adultério de Marta com, pelo menos, dois possíveis amantes, e o tumultuoso clima de homossexualidade que é sugerido em toda a narrativa. Recorde-se que a obra é publicada em 1913 num país - Portugal - em que ainda hoje se poderia observar uma sociedade bastante conservadora.

O triângulo amoroso, previsivelmente, termina em um crime, um assassinato, com o uso de uma arma moderna, um revólver. A trama, sobretudo, é típica de um romance policial, na qual o autor soube manipular devidamente os recursos capazes de criar e intensificar o mistério, numa ambientação obscura e ambígua.

Além disso, há uma tematização espírita já referida por Maria Helena Nery Garcez. ${ }^{15}$ O espiritismo de Allan Kardec, cujos livros começaram a ser publicados em Paris a partir de 1857, alastrava por toda a Europa a práxis de fenômenos mediúnicos, ${ }^{16}$ atraindo para si um público cada vez maior e cada vez mais interessado em seus mistérios inexplicáveis, e por isso mesmo, fantásticos.

Há de se levar em conta que essas características implicam em uma recepção coerente com uma literatura de consumo, qual seja, aquela ingênua e quase pragmática, provocadora de uma realidade ilusória. Karlheinz Stierle afirma que, nesse tipo de literatura, "os diferentes momentos são organizados de forma a liberar os estereótipos da imaginação e da emoção e, simultaneamente, a ocultar que a própria

${ }^{15}$ GARCEZ, 1989.

${ }^{16}$ AREAS. Op.cit. p.64. 
linguagem os tenha desencadeado". ${ }^{17}$ É a recusa de uma recepção verdadeiramente ativa e conseqüente expulsão do leitor na produção da obra literária. Firma-se aqui, da mesma forma, uma oposição às idéias de Adorno, ou melhor: a obra passa a agradar ao mercado e ao mundo burguês tão desprezados pelo filósofo alemão.

Considere-se ainda que, na obra, à temática historicamente moderna - inserida num clima cosmopolita onde artistas e libertinos freqüentam cafés, luxuosas mansões, teatros e music-halls - conformase uma declarada alienação social. A Paris do final do século XIX é descrita como local de discussões mundanas e estéticas, cujo engagement é nulo: não há, em A confissão de Lúcio, referências à conturbada política da época, como não há relatos ou diálogos onde se pudesse perceber uma preocupação social. Lembre-se que, no período, o mundo estava às portas de uma guerra, e a Revolução Industrial - há um bom tempo em vigor na Europa - estabelecia um operariado vincadamente miserável, que já tinha experimentado revoltas e rebeliões. Paris, por exemplo, estava repleta de prostitutas, muitas vezes operárias de dupla jornada que exploravam o corpo para complementar o salário. ${ }^{18}$

Todavia, nada disso é manifesto na obra. A grande cidade e a vida modernas, firmadas em pontes, estradas férreas e torres de aço (p.83), parecem estar para os artistas - seja escultores, poetas, pintores, dramaturgos e atores - e para uma ou outra "criaturinha": "todas iguais, sempre - vestidas dos mesmos fatos, com as mesmas pernas nuas, as mesmas feições ténues, o mesmo ar gentil” (p.80). Uma única vez aparecem como possíveis costureiras, "decerto saídas dos ateliers da Rua da Paz", porém, mesmo assim, descaracterizadas, "dando gargalhadas", "gentis e risonhas" (p.87). O meio cosmopolita freqüentado pelas personagens, onde se discutem "modas, teatro e music-hall, com muita arte à mistura" (p.66), parece pertencer a pessoas como Ricardo, que assim se descreve, segundo a narração de Lúcio:

\footnotetext{
${ }^{17}$ STIERLE. In: JAUSS, 1979, p.150.

${ }^{18}$ Cf. ARÊAS. Op.cit.p.62.
} 
Dentro da vida prática nunca me figurei. Até hoje, aos vinte e sete anos, não consegui ainda ganhar dinheiro pelo meu trabalho. Felizmente não preciso... E nem mesmo cheguei a entrar nunca na vida, na simples Vida com V grande - na vida social, se prefere (p.79).

É importante verificar, contudo, que essas constatações, se por um lado colocam a obra à mercê de um crítico moralizador que enfatizaria sua cumplicidade com o comércio e com a alienação social, são, por outro lado, coerentes com as propostas modernistas da época. A obra surgiu em um período histórico propício para manifestações em favor da alienação social. Deve-se apontar, sobretudo, que para um artista se inserir na modernidade estética, ele havia de negar a modernidade dita tecnológica, responsável por grande parte da miserabilidade reinante no fim do século XIX. ${ }^{19}$

Da mesma forma, há de se recordar que Mário de Sá-Carneiro e Fernando Pessoa, em conjunto com outros artistas portugueses, participavam de discussões viscerais sobre a necessidade de se elaborarem obras onde se tornasse clara a intenção de exibir virtuosismos e blagues, afigurando-se como radicais e polêmicos contrapontos às obras consagradas do tempo, ${ }^{20}$ todas positivamente cúmplices da sociedade burguesa em vigor. É o movimento que dá origem ao grupo da revista Orpheu, com o seu primeiro número saindo em 1915, dois anos após a primeira edição de A confissão de Lúcio.

Essa sociedade burguesa, ou melhor, esse público burguês era representado pela figura já anteriormente mencionada do "lepidóptero" - um termo adotado por Sá-Carneiro para indicar a "súmula de mediocridades solenes, da parvoíce intolerante e bem instalada na vida". ${ }^{21}$ Para demonstrar a diferença incontestável dos artistas com os

\footnotetext{
${ }^{19}$ Segundo Barthes, "como a arte moderna na sua totalidade, a escritura literária traz consigo, ao mesmo tempo, a alienação da História e o sonho da História". In: BARTHES, 1977, p.167.

${ }^{20}$ GALHOZ, 1976, p.XII.

${ }^{21}$ Ibidem, p.XII.
} 
lepidópteros - em outras palavras, com aqueles sempre bem situados na sociedade e na história -, muitos componentes do Orpheu, por exemplo, chegavam a se declarar monárquicos - num mundo em que a moda "compulsória" era o republicanismo. ${ }^{22}$

Galhoz aponta que, nas duas primeiras décadas do século XX, o progresso cosmopolita no mundo das artes chocou-se com o que havia de mais espantoso e inacreditável, a Guerra, gerando um senti-mento "que se enraíza como uma força determinante na consciência do homem: a náusea" ${ }^{23}$ determinando com esse traço o modernis-mo. Para os artistas, estava claro que a Guerra era um produto da política burguesa, o que chegava a provocar efeitos desorientadores, como o caracterizado por Sá-Carneiro que, em plena guerra contra a Alemanha, escreve um poema - "Serradura" ${ }^{24}$ - no qual refere a possibilidade de sair para a rua a gritar "Viva a Alemanha".

Sobre o escritor português, é extremamente complexa a sua definição como colaborador, conformista ou resistente. Não há como situá-lo na imoralidade, a não ser que se identifique em sua postura uma a-moralidade, típica de todo artista moderno, verdadeira posição de um esteta.

Urbano Tavares Rodrigues o caracteriza como "manifesta e estranhamente associal" 25 , reagindo com antipatia às pulsações coletivas e aos frêmitos da multidão:

Com sarcasmo, entre depreciativo e receoso, fala Mário de Sá-Carneiro dos 'democráticos', e tal expressão significa para ele, mais do que uma atitude política, um plebeísmo assumido, a falta de gosto e de reserva, a incompreensão da arte. ${ }^{26}$

\footnotetext{
${ }^{22}$ GALHOZ, 1959, p.XXIII.

${ }^{23}$ Ibidem, p.XXXIII.

${ }^{24}$ SÁ-CARNEIRO, s/d, p.17.

${ }^{25}$ RODRIGUES. Prefácio. In: SÁ-CARNEIRO, 1958 e 1959, p.15.

${ }^{26}$ Ibidem, p.15-16.
} 
Para o autor de A confissão de Lúcio, a sociedade da época estava eivada dos "democráticos": figuras populares que disputavam os lugares das tribunas e que, com base numa verbalização muitas vezes vazia e essencialmente pragmática, eram capazes de inebriar o público, tornando-se heróis a despeito do sofrimento comum. Galhoz aponta no autor um sarcasmo, um anti-burguesismo burguês, uma "repugnância pessoalíssima, feita de esteticismo vingativo, de vulnerabilidade e de timidez oculta". ${ }^{27}$ Mário firmar-se-ia como um rebelde esnobe, avesso à sociedade e aos seus dirigentes, e determinaria a sua ação por uma eloqüente inação: "toda e qualquer pregação com pretensões construtivas, nele encontraria sempre um eco entediado e irônico". ${ }^{28}$

\section{Uma arte política}

Dessa forma, tendo em vista o solo histórico e poético de onde germinou, A confissão de Lúcio sempre há de conformar uma atitude de irônica voluntariedade estética, seja por sua aparente combinação com o comércio e alienada a-historicidade anti-social, seja por seu desprezo ao público caracteristicamente burguês da época, ávido por obras bem comportadas e facilmente assimiláveis, proporciona-doras de edificação espiritual e social. A obra, ao expor personagens libertinas, desvinculadas de um discurso político e social à moda da época, e compromissadas unicamente com suas vidas no que elas apresentam de volúpia e mistério, é desprovida de vínculos referentes a uma moralidade ou a uma verdade histórica.

Ela poderia visar ao público somente no sentido de ansiar a provocação e o embate, conforme a ditada prática de Orpheu. Nessa prática, a obra poderia estar direcionada sobretudo ao grupo de amigos tendo em conta os seus comentários, sendo o sucesso com o público um feliz e perverso acaso:

\footnotetext{
${ }^{27}$ GALHOZ, 1959, p.XIII.

${ }^{28}$ RODRIGUES. Op.cit. p.16.
} 
1912, em Lisboa. Alguns rapazes da, então, geração nova começam, por essa altura, a encontrar-se - literária e inevitavelmente - pelos cafés da Baixa. Jovens, a preocupação da sua juventude em dia com 'lá fora' levaos ao desafio duma originalidade espectacular e mergulha-os no entusiasmo deliciado de escandalizar o respeitável e 'lepidóptero burguês'. Ao lado desta piada de entre jornal e café, seu signo exterior de conversas e atitudes, ideias, projectos, vontades de afirmação e amizade. Uma amizade autêntica, pronta, existente, que será a mais forte razão íntima da aventura órfica. ${ }^{29}$

A obra, assim, firma-se novamente - de acordo com o pressuposto pêndulo - enquanto resistência, ao se dispor contra uma sociedade que via na arte um convincente instrumento de doutrinação e de manipulação política, levando em conta o fortalecimento da "democracia". Ou, então, como um inútil e vazio passatempo de alguns jovens da época que não sabiam se relacionar devidamente com a realidade. Pode-se dessa maneira deduzir que o único projeto ostensivamente político observado em suas páginas é o projeto de exaltar a melhor forma de fazer política: optar pela relatividade ao fazer arte.

\section{Rerefências Bibliográficas}

ADORNO, Theodor W. Teoria estética. (sem referências sobre o tradutor). Lisboa: Edições 70, 1980.

Anais da Semana de Estudos Mário de Sá-Carneiro. Belo Horizonte: Centro de Estudos Portugueses FALE/UFMG, 1994.

ARISTÓTELES. Poética. Trad. Eudoro de Souza. São Paulo: Nova Cultural, 1991.

BARTHES, Roland. Ograu zero da escritura. Trad. Antonio Gonçalves. Lisboa: Edições 70, 1977.

${ }^{29}$ GALHOZ, 1959, p.XIII. 
BARTHES, Roland. Oprazer do texto. Trad. Maria Margarida Barahona. Lisboa: Edições 70, 1974.

BÉGUIN, Albert. L'âme romantique et le rêve. Paris: Librairie Jose Corti, 1946.

BENJAMIN, Walter. O conceito de crítica de arte no romantismo alemão. Trad. Marcio Seligmann-Silva. São Paulo: Iluminuras, 1993.

CANDIDO, Antonio. O romantismo, nosso contemporâneo. Jornal do Brasil, Rio de Janeiro, mar.1988. Idéias, p.2.

FINLAY, Marike. The romantic irony of semiotics - Friedrich Schlegel and the crisis of representation. Berlin: Mouton de Gruyter, 1988. (Trad. do grupo que estuda a ironia literária na FALE/UFMG).

GALHOZ, M. A. . O momento poético do Orpheu. In: Orpheu. Reedição do vol. I. Lisboa: Ática, 1959. p.IX-LI.

GALHOZ, M. A.. Introdução. In: Orpheu. Reedição do vol. II. Lisboa: Ática, 1976. p.VII-LXVIII.

GARCEZ, Maria Helena Nery. Trilhas de Fernando Pessoa e Mário de Sá-Carneiro. São Paulo: Editora Moraes/EDUSP, 1989.

HEGEL, G.W.F. Estética-a idéia e o ideal. Trad. Orlando Vitorino. São Paulo: Abril Cultural, 1974.

HEGEL, G.W.F. Esthétique-Textes choisis. Trad. Claude Khodoss. 12.ed. Paris: Presses Universitaires de France, 1992.

JAUSS, Hans Robert et al. A literatura e o leitor - textos de estética da recepção. Coord. e trad. Luiz Costa Lima. Rio de Janeiro: Paz e Terra, 1979.

Mário de Sá-Carneiro. Colóquio/Letras. Lisboa: Fundação Calouste Gubenkian, 1991.

NOVALIS. Pólen. Trad. Rubens R. Torres Filho. São Paulo: Iluminuras, 1988.

NOVALIS. Fragments. Paris: Aubier Montaigne, 1973.

SÁ-CARNEIRO, Mário de. A confissão de Lúcio. Lisboa: Publicações Europa-América, 1989. 
SÁ-CARNEIRO, Mário de. Cartas de Mário de Sá-Carneiro a Fernando Pessoa. Obras completas. 2 vols. Lisboa: Ática, 1958 e 1959.

SCHLEGEL, Friedrich. Conversa sobre a poesia e outros fragmentos. Trad. Victor-Pierre Stirnimann. São Paulo: Iluminuras, 1994.

SCHLEGEL, Friedrich. Obras selectas. Trad. Miguel Angel Vega. Madrid: Fundacion Universitaria Española, 1983.

\section{Resumo}

Este trabalho pretende analisar determinados aspectos inseridos na relação entre arte e mercado levando-se em consideração as concepções do filósofo Adorno e do escritor Mário de Sá-Carneiro.

\section{Résumé}

Ce travail essaye d'analyser quelques propositions sur le raport entre l'art et le marché en consideránt les conceptions du philosophe Adorno et de l'écrivain Mário de Sá-Carneiro. 